\title{
Effects of Cybercrime on State Security: Types, Impact and Mitigations with the Fiber Optic Deployment in Kenya
}

\author{
Peterson Obara Magutu ${ }^{1}$, Gladys Monchari Ondimu ${ }^{1}$ and Christopher Jilo Ipu ${ }^{2}$ \\ ${ }^{1}$ Department of Management Science, School of Business, University of Nairobi, Nairobi - Kenya \\ ${ }^{2}$ Department of Political Science, Strategic Security Studies at Faculty of Arts, University of Nairobi, \\ Nairobi - Kenya
}

\begin{abstract}
The identification of Information and Communication Technology (ICT) as an essential tool for sustainable development has proved to be worth every investment. As a result of this, Internet usage in Kenya has grown rapidly resulting in the explosion of Internet Service Providers (ISPs) and Internet access points. The general objective of this study was to model the impact of Cybercrime on security in Kenya, Nairobi as the case study. This was a census study on modeling the effects of Cybercrime on the security in Nairobi. Thirty one (31) out of the fifty one (51) responded giving a response rate of $60.78 \%$ percent. It was found that the Cybercrime is prevalent in Nairobi although largely unreported. To a great extent, it was discovered that Internet Service Providers had established basic measures in order to curb the growing cyberspace crimes; as spamming activities remain prevalent in Kenya. Also, to a great extent the Criminal Investigation department (CID) and Communications Commission of Kenya (CCK) have recognized that cybercrime is a growing threat to security in Nairobi and have collaborated with ISP's to implement measures.
\end{abstract}

Keywords: State Security, Cybercrime, Types, Impact \& Mitigations

\section{Introduction}

\section{Background}

Cybercrimes poses a great threat to the national security of all countries, even technologically developed countries like the USA suffer from it (Darpan, 2008). These cyberspace crimes results in companies and government institutions to lose billions of dollars, for example, the Russian organized crime groups were known to be involved in telecommunications fraud including cloning cellular phones, which cost billions in lost revenues. The Russian groups also targeted bookmakers and online betting sites and made demands for ransom or threaten to shut down their network if they failed, their activities costed the FBI, Interpol and other British and Australian authorities millions of dollars in trying to investigate and apprehend such groups (Mallory, 2007).

Abuse and misuse of computer systems have existed nearly since mainframe computers were first invented during the 1940 s and 1950 s as a means to improve military munitions and then rocket guidance systems. By the mid 1970s researchers began studying "computer abuse" because in those days, harmful activities committed with computers were not prohibited by computer crime laws. By the 1980s all this began to change, with more and more computers interconnected 
via the Internet, more abuses of computer systems drove state governments and the federal government to begin passing computer crime laws. Initially these laws focused on the growing phenomenon of computer hacking, but were soon expanded into other types of criminal behaviors. In effect, computerization made possible by inventions and innovations in computing and telecommunications technologies also made possible, if not inevitable, the concept of "computer crime." This concept, however, became outdated as computer technologies became smaller, more powerful, more affordable, and capable of performing many tasks including uploading and downloading data files on the Internet (McQuade, 2009).

This social transformations wrought by Internet technologies has made the future appear insecure and unpredictable, yielding public and political overreaction. Such 'moral panics', fuelled by the media, lead to an excessive and unjustified belief that particular individuals, groups or events present an urgent threat to society (Critcher, 2003). Internet-related instances of such panics include those over the effects of pornography in the mid-1990s, and more recently over threats to child safety from pedophiles (Littlewood, 2003). The emergence of the World Wide Web, along with a myriad of software applications, online content, and the beginning of broadband internet connections, computer crime has evolved into computer-related crime and then what we refer today as cybercrime. Today computer networks are more accurately referred to as information systems.

The largest information system in the world is the Internet, although there are many regions and parts to this giant network. The Internet is seen as part of the globalization process that is supposedly sweeping away old realities and certainties, creating new opportunities and challenges associated with living in a 'shrinking' world. We are now said to be in the midst of a 'new industrial revolution', one that will lead us into a new kind of society, an 'information age' (Webster, 2003).

Yet, awareness of and enthusiasm for these changes have been tempered by fears that the Internet brings with it new threats and dangers to our well-being and security.
Cyberspace, the realm of computerized interactions and exchanges, seems to offer a vast range of new opportunities for criminal and deviant activities (Yar, 2006).

This has presented a challenge to information technology professionals who lack an awareness of an interest in the cybercrime phenomena. In many cases the law enforcement officers have lacked the tools needed to tackle the problem; old laws haven't quite fit the crimes being committed, news laws haven't quite caught up to the reality of what is happening, and there were few court precedents to look for guidance (Shinder,2002).

\section{The Concept of Cybercrime}

The concept of cybercrime is not so much different from that of conventional crime as both include conduct, whether act or omission, which cause breach of rules of law and counterbalanced by the sanction of the state. Current definitions of Cybercrime have evolved experientially and differ depending on the perception of both observer/protector and victim. The Council of Europe's Cybercrime Treaty uses the term "Cybercrime" to refer to offences ranging from criminal activity against data to content and copyright infringement. However, according to Zeviar-Geese (1998), he suggests that the definition is broader including activities such as fraud, unauthorized access, child pornography, and cyber-stalking. Cybercrime is a subcategory of computer crime and it refers to criminal offenses committed using the internet or another computer network as a component of the crime (Shinder,2002). Schell(2004) defined cybercrime as a crime related to technology, computers and the internet and it concerns governments, industries and citizens worldwide where cybercrime takes the form of either piracy, phreaking (obtaining free telephone calls), cyberstalking, cyberterrorism and cyberpornography. Milhorn, (2007) on the other hand, simply defines cybercrime as any activity that uses the internet to commit a crime.

According to Taylor(1999), when speaking about cybercrime, usually it is about two major categories of offences. In one, a computer connected to a network is the target of the offence and this is the case of 
attacks on network confidentiality, integrity and/ or availability. The other category consists of traditional offences such as theft, fraud, and forgery which are committed with the assistance of/or by means of computers connected to a network, computer networks and related information and communications technology.

Richards (1999) argues that to define cybercrime, it is important to understand the different types of crimes that can be linked to computers, for example, hacking into a telephone service to enjoy free telephone calls is a type of computer crime and pirating software is another. Whatever forms computer crimes take, the characteristics that make computer systems, particularly computer banking systems, so attractive for legitimate purposes, that is, security, efficiency, anonymity make them similarly attractive for illegitimate purposes such as money laundering. According to Wall (2001), the internet has impacted upon criminal or harmful activity in three ways; first, the internet has become a vehicle for communications which sustain existing patterns of harmful activity, such as drug trafficking, hate speech, stalking and so on. Newspapers for example, circulate information about how to bypass the security devices in mobile telephones or digital television decoders (Mann \& Sutton, 1998).

Secondly, the internet has created an environment that provides new opportunities for harmful activities that are currently the subject of existing criminal or civil law, for example, pedophile activity and fraud. Third, the nature of the virtual environment, particularly with regard to the way that it distanciates time and space, has engendered entirely new forms of harmful activity such as the unauthorized appropriation of imagery, software tools and music products (Giddens, 1990). These three levels invoke different policy responses and require quite different bodies of understanding. Jurisdictional dilemma is one factor that makes the definition of cybercrime difficult as laws in different jurisdictions define the terms differently and the lack of concrete statistical data on these offences imposes another major problem. As from the above definitions, Cybercrime can be defined as any crime that is facilitated or committed using a computer, network, or hardware device. The computer or device may be the agent of the crime, the facilitator of the crime, or the target of the crime. The crime can take place on the computer alone, or in other non-virtual locations.

Unauthorized access of hosts more commonly known as hacking, can take various forms some of which might not always involve deep technical knowledge. It involves using a computer or terminals to crack the security of some computer systems. Cybercriminals use snifters or just by guessing passwords to breach security greatly diminishing the effectiveness of passwords when users do not select wisely (Adomi,2008).

Spamming involves flooding the internet with many copies of the same message to multiple addresses. A spammer sends millions of emails in hope that one or two percent will find their way into inboxes and that a further one or two percent will generate a response. Spam messages are always sent with false return address information and they are also referred to as junk mail (Milhorn, 2007).

All stages of computer operations are susceptible to criminal activity, either as the target of fraud, the instrument of fraud, or both. Input operations, data processing, output operations and communications have all been utilized for illicit purposes. The more common types of computer fraud include, fraud by computer manipulation where intangible assets that are represented in data format such as moneyon-deposit or hours of work, are the most common targets of computer related fraud. Modern business is replacing cash with deposits transacted on computer systems, creating an enamours potential for computer fraud. The organized criminal community has targeted credit card information, as well as personal and financial information about clients. The sale of this information to counterfeiters of credit cards and travel documents has proven to be extremely lucrative (Siegel, Saukko, \& Knupfer , 2000).

Viruses, Trojans and Worms all fall into a similar category as they are software designed to infect computers or install themselves onto a computer without the 
users permission, however they each operate very differently. A typical virus does two things, first, it copies itself into previously uninfected programs and secondly, it executes other instructions that virus creator has included in it. Some viruses do not have any harmful instructions at all, instead they cause damage by replicating and taking up disk space (Adomi, 2008). Malicious code is any software program designed to move from computer to computer and network to network, in order to intentionally modify computer systems without the consent of the owner or operator. It includes viruses, Trojan horses, worms, script attacks and rogue Internet code. Computer viruses have been around for almost as long as computers (Grimes, 2001).

Another major element of cybercrime is piracy, which refers to the illegal copying of software and games, movies, music and other digital media. Piracy is relatively easy to undertake quite often requiring not more than a CD-RW or DVD-R/RW drive that can replicate the original CD's or DVD's on which a particular application is stored. Applications, games, and music can also of course be simply copied onto the internet for download (Bell, 2004).

Cyberstalkng and cyberharassment has been described by Yar(2006), as the persistent and targeted harassment of an individual via electronic communication such as email. Cyberstalking has been defined as the repeated use of the Internet, email or related digital electronic communication devices to annoy, alarm, or threaten a specific individual (D'Ovidio and Doyle, 2003) .

Cyberstalking, also called online stalking or online victimisation, shares important characteristics with offline stalking. The similarities are that, first, the majority of cases involve stalking by former intimates, although stranger stalking certainly occurs in the real world and in cyberspace; second, most victims are women and most stalkers are men. Third, stalkers are believed to be motivated by the desire to control the victim.

Cyberterrorism which has become a very emotive topic partly because of the dramatic imagery that it evokes using computers to attack the physical infrastructure to generate mass fear and anxiety and, in theory, manipulate the political agenda (Wall, 2007).

Cyberterrorism is the convergence of terrorism and cyberspace. It has been defined as premeditated, politically, motivated attack against information, computer systems, computer programs, and data which result in violence against non combatant targets by sub national groups or clandestine agents. Attacks that lead to death or bodily injury, explosions, plane crashes, water contamination, or severe economic loss would be examples. Serious attacks against critical infrastructures could be acts of cyberterrorism, depending on their impact (Khosrowpour, 2004).

\section{The Development of the Internet Service in Nairobi, Kenya}

Development of the Internet in Kenya took place in three broad phases. The first phase, which ran from 1990 to 1998, witnessed the introduction of the Internet largely by Kenyans returning from studies overseas, western expatriates, and personnel of Inter-governmental Organizations and NGOs. Commercial ISPs entered the Internet market by the mid 1990s, primarily offering dial up and content services.The early adopters of the Internet included import/export sector, industries with overseas clients and the academic sector. Most of the Internet users then were confined to the Capital City, Nairobi. As the number of ISPs and Internet users increased, the need for an Internet backbone became evident and the defunct Kenya Posts and Telecommunications Corporation established one in 1998. The key challenges in the 1990s included limited and high cost of international Internet bandwidth; the high cost of both dial-up and domestic leased lines; the limited penetration of PCs; lack of policy and regulatory environment; and the lack of appropriate IT skills (Njoroge,2009).

As described by Njoroge, the second phase took place from 1999 to 2004 with the Government of Kenya restructuring the communications sector with a view to introducing competition and to pave way for private sector participation. As a result, an independent ICT sector regulator, the Communications Commission of Kenya 
(CCK) ,was established to spearhead sector reform. A number of positive developments took place during this phase, the most notable were the establishment of an Internet Exchange Point (IXP) by the private sector and the successful redelegation of the administration of dot KE ccTLD through a public private partnership. The elapse of Telkom Kenya's exclusivity in June 2004 in the provision of various services including Internet bandwidth marked the grand entry of the third phase of Internet development in Kenya.

The ICT industry had been anxiously waiting for the lapse of the exclusivity to have a share of the services hitherto reserved for the incumbent. The most notable features of the post-exclusivity regime was introduction of competition in all business segments previously reserved for the incumbent, including internet backbone, Voice over IP, satellite and international voice gateway services. In addition, the regulator expanded competition in the cellular mobile telecommunications market from two to four networks, triggering off the deployment of a wide range of innovative products and services, including mobile Internet and a host of value added services such as, M-Pesa. As a result of this new wave of reforms, coupled with increase in the penetration of PCs and in the level of IT skills, the number of regular Internet users in Kenya increased to the region of 3 million out of a total population of 35 million.

The deployment of national broadband fibre optic connectivity to take advantage of the three sub-marine cables competing to land at our coastal city of Mombasa is expected to lower the cost of Internet access and thus spread the digital dividends to a bigger proportion of Kenyans. The projects will also make egovernment a reality in the country. Today, a number of mobile companies are providing $3 \mathrm{G}$ mobile Internet services at very competitive rates and with the recent adoption of the Unified Licensing Regime, there is no doubt that Kenya should have close to 50 per cent Internet penetration by 2013.

\section{Statement of the Problem}

The research intended to establish the types, impact and mitigations of cyber crime with the deployment of fibre optic cable in Kenya security.

Kenya had not attracted this sort of cyberspace crime largely because of the slow Internet connectivity which had been available only in selected urban centers. The recent emergence and development of the broadband fibre optic connectivity will certainly and inevitably expose Kenya to high levels of Cybercrime. This research intends to study the forms of cybercrime in Nairobi and the emerging threats brought about by the recent internet development through the fibre optic cable.

Although cyber-crime has been around for nearly 30 years, research in the area has been sparse (Chandler, 1996). A major problem for the study of cybercrime is the absence of a consistent current definition even among those law enforcement agencies charged with tackling it (Yar, 2006). As Wall (2001) notes, 'the term has no specific referent in law', yet it is often used in political, criminal justice, media, public and academic discussions.

Research of cybercrime is in its infancy, this is because knowledgeable individuals and institutions both in the public and private sectors may for commercial, political or national security reasons be disinclined to share their wisdom with researchers (Roderic,2005). According to Yar (2006), our awareness of the Internet's criminal dimensions has certainly been cultivated and heightened by mass media representations. The news media have played their part in identifying and intensifying public concerns, and hardly a day goes by without some new report of an Internet-related threat.

According to one of the studies by Tushabe and Baryamureeba (2005), cybercrime was found to be silent but common in East African countries and concluded that cybercrime is a serious threat to the security of cybercitizens and all countries should take it seriously. Their study 
realized that cybercrime instances are mainly discussed socially and the victims suffer in silence, while the perpetrators continually hide under the invisibility of the cyber world and it is hard to convict cyber criminals because of two major reasons. Firstly, few countries have enacted e-laws and the existing ones are not sufficient in convicting culprits because of jurisdiction anomalies especially when the investigation transcends international borders. Secondly, obtaining evidence of computer crime that would stand in courts of law is lacking in many countries since the field of computer forensics is still relatively new and lacks sufficient literature and expertise.

Although a number of researches had been done on the cybercrime, none had focused in Kenya, particularly Nairobi. The Kenyan internet structure has seen a revolution with the emergence of the fibre which will place Kenya at the same level as first world economies and will certainly drive growth especially after a time that Internet in Kenya has been referred to as being inadequate, inefficient and of high cost. The advent of high speed connectivity will draw the attention of local and international hackers who were previously put off by the amount of time it took to break into local websites using slower satellite connections, this is because Nairobi is slowly being recognized as a regional hub for internet connectively not only in Kenya but regionally and this is largely being driven by affordable and reliable Internet connectivity projected from the emergence of the fibre optic cable. (Kinyanjui, 2009). Recently, Hewlett Packard (HP) made Nairobi the regional hub for East and Southern Africa for its Personal Systems Group, where The Nairobi office will serve 18 sub-Saharan countries (Ngunjiri, 2008).

At this moment, the most serious threat to the economy is seen as the lack of security online. This study therefore seeks to identify the different forms of cybercrime prevalent in Kenya, with Nairobi as the case study and the effects of these threats on security. Also the study sought to identify the emergent threats imposed by the recent internet development through fibre optic and its probable implications on security. The research questions were:
- To determine the types of Cybercrime prevalent in Kenya;

- To investigate the impact of cybercrime on Kenyan security.

- To assess the security employed by ISP's \& other organizations to curb cybercrime as imposed by the recent fibre optic development in Kenya

\section{Research Strategy}

The guiding principles here were the objectives of the study. A survey research design sought information about the effects of Cybercrime on state security in Kenya. This study had the privilege of providing in-depth analysis on the recent internet development in Kenya and the challenges it imposes on state security.

The population of the study consisted of the fifty one (51) ISP's in Kenya registered by the CCK, it will consist also of the CID who hold vital statistics to cybercrime reported in Nairobi, and the CCK who enforce regulations on all registered ISP's in Kenya, currently there're 51 ISP's registered by the CCK(See Appendix I). The research targeted the IT staff in the above selected study population (both in the Senior and low level management). The sample frame constitutes of both the Senior and Junior management level where simple and stratified sampling was employed to select the respondents in this study. Stratified sampling was used to ensure that the various entities in the population are well represented in the sample and to ensure accuracy. With Simple Random Sampling, a random sample was selected such that every element in the population will have an equal chance of being included into the sample and the respondents selected will each be interviewed discretely.

The mechanisms employed in data collection included the use of both questionnaires and interviews (See appendix II). The questionnaires were preferred in this study because those who took part in this study were considered to be literate and capable of answering the questions sufficiently. For quicker response the use of email to administer the 
questionnaires was employed, apart from personal visits to the respondents where a drop and pick later approach was employed. Interviews were conducted with the use of both structured and semistructured modes of interview. Telephone interviews were hereby preferred to facilitate the research especially for areas where physical access to respondents was limited, for example, the Criminal Investigation Department (CID). The questions were structured in such a way that for fixed response questions were rated against five points scale, from extremely significant (5) to not significant(1). Room was provided for personal responses not captured in the fixed response- questions. The responses that were obtained were compared to the literature review to establish the significant implications of cyber-crime on security.

The data from respondents was analyzed using descriptive statistics such as means, percentages and tables. SPSS (Statistical Package for Social Scientists) was used to analyze the data.

\section{Data Analysis and Findings}

Data was collected from (51) institutions with only 35 of them responding.

Cybercrime is simply as any activity that uses the internet and computers to commit a crime. All the IT staff interviewed consented to their knowledge and existence of Cybercrime in Kenya.

\section{Forms of Cybercrime Prevalent In Kenya}

There are a number of forms of cybercrime. The respondents were asked to indicate the forms of cybercrime prevalent in Kenya, on a five likert-scale where Very Great Extent = 5; Great Extent $=4 ;$ Average extent $=3$; Small Extent $=2$; Very Small Extent $=1$. The results are shown on table 4.1

Table 4.1 Forms of cybercrime in Kenya

\begin{tabular}{|l|l|l|}
\hline Forms of Cyberspace crime & Mean & $\begin{array}{l}\text { Std. } \\
\text { Deviation }\end{array}$ \\
\hline Spam & 4.70 & .466 \\
\hline Viruses \& Trojans & 4.43 & .504 \\
\hline Hacking & 4.27 & .450 \\
\hline Piracy & 4.10 & .305 \\
\hline Phishing & 3.87 & .681 \\
\hline Cyberpornography & 3.13 & .681 \\
\hline Denial of service & 2.60 & .770 \\
\hline Cyberespionage & 1.47 & .730 \\
\hline Cyberstalking & 1.20 & .407 \\
\hline Cyberterrorism & 1.07 & .254 \\
\hline
\end{tabular}

Source: Research Data

From the results in table 4.1, it was found that, Spam, virus and trojan attacks, hacking and piracy, were the leading cyberspace crimes experienced by IPSs. Most of the reports to the given data were reported to the system administrators where victims hoped to recover lost or damaged data. Otherwise most victims preferred to keep quiet because they do not think reporting would help them since preserving evidence is unknown to them. These statistics show that Kenyans and internet users are initiating and falling victim of cybercrime, although the public are not reporting to the relevant authorities either because of non-existent 
sensitization programs or hopelessness due to the unavailability of e-laws that would bring them justice.

Other cyberspace crimes that are emerging include; Cyberespionage, Denial of Service attacks, Cyberterrorism and Cyberstalking. These can be explained to be at the bottom of the table largely as a result of the fact that, internet in Kenya is still developing where internet is still expensive and limited but once the fibre connectivity is fully operational these threats are feared to be escalated, since internet will be readily available at cheaper rates and bandwidth connectivity will compare to first world economies. Cyberterrorism the most feared of them all poses a great danger especially as the government plans to inter-connect all its ministries through e-governance. It faces a deadly threat where its operations may be interrupted through denial of service attacks that could cripple vital services. Again, cyberespionage may be used to steal or expose critical information by covert organizations intending to sabotage the state.

According to the Criminal Investigations Department (CID), In January 2005 [11], a multi-million dollar scam involving a fraudulent intranet bank transfer between Standard Charted Bank, Nairobi and Barclays Bank, Kampala was unveiled. A prominent Ugandan businessman and construction magnet, Andrew Zzimwe Kasagga together with two Congolese nationals were wanted by Interpol (Kenya) over accusations of masterminding the bank fraud that saw Kenyan Standard Chartered Bank staff wiring to them $\$ 5$ million in three installments to separate bank accounts and recipients in Kampala. Suspected conmen got the Nairobi based bank to wire one million dollars to Zzimwe's Barclays Bank account in Kampala and another \$2 million from Kenya was intercepted at Crane Bank. It had allegedly been sent to another suspect, Kampala lawyer, Paul Kalemera. Further investigations and trial are being conducted. Another \$3 million being swindled from Kenya was detected before it was sent to forex bureaux via the DFCU bank in Kampala.
Also according to an article published in the Nation newspaper on 8th August 2009, childpornography is on the high increase, where internet development in Nairobi has enabled criminals to promote this vice. According to the article, pornography materials are easily downloaded from the internet and burned using DVD/Writers and the DVD's sold for as little as 300, what is alarming is the fact that children as young as nine years were watching the movies that were also openly advertised on the Nairobi streets.

\section{Challenges Curbing Cybercrime}

There are a number of strategies employed by various organizations some specific to particular cybercrime forms and some general for instance, antispam which is specific to preventing the proliferation of spam mails into client accounts which is also a part of CCK requirement to ensure that clients are protected. General strategies against cyber crime include use of firewalls and bandwidth shaping tools, for instance, the Canadian developed Sandvine equipments which limit bandwidth choking and efficient way of controlling piracy.To satisfy one of the specific objectives outlined on the first chapter, on the challenges faced by ISP's in curbing cybercrime, it was necessary to query the respondents further on the specific challenges they face in fighting cyberspace crime. On an interview with a senior management staff at Orange Telkom staff observed that the use of bandwidth shaping tools allowed them to control how users on the cyberspace downloaded media files such as movies and music, this strategy not only prevented the users from starving other users from bandwidth but also controlled to some extent the piracy of copyright materials.

The respondents, therefore, were queried on a number of challenges they are facing in fighting cybercrime in Nairobi. This was on a five likert-scale where Very Great Extent $=5$; Great Extent $=4$; neither agree nor Disagree $=3$; Small Extent $=2$; Very Small Extent $=1$ where the higher values represented the extent to which the challenges had been overcome, on the 
other hand, the lower values represented the challenges that were still difficult to eradicate. The results are shown below on table 4.3

Table 4.2 Challenges Curbing Cybercrime

\begin{tabular}{|l|l|l|}
\hline Challenges & Mean & Std. Deviation \\
\hline Software evaluation & 4.71 & .488 \\
\hline Management training & 4.71 & .488 \\
\hline Compatibility issues & 4.43 & 1.134 \\
\hline Resistance to change & 4.14 & 1.069 \\
\hline Skilled personnel & 3.86 & .900 \\
\hline Adequate staff & 3.86 & 1.345 \\
\hline Cost & 3.86 & 1.069 \\
\hline Cybercrime awareness & 3.71 & .951 \\
\hline Ignorance & 3.14 & 1.069 \\
\hline Software evaluation & 2.14 & 1.345 \\
\hline
\end{tabular}

Source: Research Data

From table 4.2 it was found that to a great extent (mean $>4$ ), most of the ISP's in Kenya had employed skilled personnel who were knowledgeable in combating cybercrime, also there was low resistance to change when strategic measures were being implemented, there was also satisfactory software evaluation that also ensured there were minimum compatibility issues experienced. Finally the ISP's had also invested in conducting management training that presented the staff with the relevant knowledge of cyberspace crime that was constantly changing and the means necessary to combat them.

On the other hand, from the table 4.2 we draw conclusions that the cost of combating cybercrime in terms of purchasing the necessary equipments and applications, employment of skilled personnel and other strategies constituted a large portion of ISP budget. Apart from purchasing software firewalls the respondent revealed that it was becoming necessary to also purchase hardware firewalls together with bandwidth shaping tools to minimize the emerging crime such as piracy which also chocked the network, that is, it prevented other users from accessing bandwidth. Ignorance by both staff members and the public was also a great hindrance to the fight against cybercrime which to a great extent was as a result of lack of awareness that this type of crime exists, thus, users of the internet will fail to employ the measures required in order to safeguard themselves when on cyberspace, it is important to note that a single client infected by a virus is enough to infect other clients and servers on the network. Therefore, individual responsibility is a challenge that great undermines the fight to eradicate cybercrime.

According to the Criminal Investigations Department (CID) there are a number of challenges that have largely constituted to the poor control and eradication of cybercrime in Nairobi. Table 4.2.1 outlines the results as provided by the CID.

Table 4.2.1 Challenges Curbing Cybercrime

\begin{tabular}{|c|c|}
\hline Challenges & (\%) \\
\hline Legislation & 33.82 \\
\hline Resources & 26.57 \\
\hline Crime awareness & 22.7 \\
\hline Relevant Skills & 16.9 \\
\hline
\end{tabular}

Source: Criminal Investigations Department 
According to table 4.2.1 the greatest to challenge to cybercrime include, poor legislations presently in Kenya that are essential in combating cyberspace crime, authorities cannot obtain permission to search and prosecute offenders of this crime without proper laws that will enforce them, for this reason, cybercriminals do not have the fear of being apprehended and continue to commit this crime. The issue of jurisdiction also makes on one country irrelevant for instance, a crime committed in Uganda where cybercrime laws are ineffective or non-existent makes apprehension almost impossible.

The lack of sufficient resources for instance, funds which would enable authorities purchase equipments and applications, necessary to collect evidence and also applications and instruments to detect and prevent such crime from happening are quite limited. Finally, lack of awareness to this type of crime and also lack of relevant skills constitute to the remainder of these challenges, where legislators who are responsible for enacting laws cannot enforce into law what they do not understand. Authorities on the other hand, lack necessary skills that afford them the capacity to employ efficient strategies in detecting and in collecting digital evidence crucial in prosecuting cyberspace offenders.

\section{Preventing Cybercrime}

Presently in Nairobi, Kenya, local ISP's are adopting a number of measures as directed and required by the CCK in order to establish client or user security and also ultimately reduce cybercrime. These measures vary and they are primarily instituted to control cybercrime from the public as much as possible, who largely are not aware that this crime exists. The ISP's also find themselves going a notch further than CCK's standard requirements to adopt different other strategies to curb cybercrime. The advent of the cyber optic cable also symbolizes a new information revolution age in Nairobi as internet is expected to be much more affordable and internet bandwidth will be offered at much more faster speeds, competitive with those of the first worlds. The respondents were asked to identify the various strategies they had employed in order to curb cybercrime. This was on a five likert-scale where Very Great Extent $=5$; Great Extent $=4$; Average extent $=3$; Small Extent $=2$; Very Small Extent $=1$. The responses are as table 4.3.

Table 4.3 Preventing Cybercrime (Descriptive Statistics)

\begin{tabular}{|l|l|l|}
\hline Preventing Cybercrime & Mean & $\begin{array}{l}\text { Std. } \\
\text { Deviatio } \\
\text { n }\end{array}$ \\
\hline Hardware firewall & 4.67 & .51640 \\
\hline Antispam & 4.50 & .54772 \\
\hline Antivirus & 4.50 & 1.22474 \\
\hline Software firewall & 4.17 & .40825 \\
\hline Data recovery & 3.83 & .98319 \\
\hline Staff training & 3.8333 & 1.16905 \\
\hline User policies & 3.8333 & 1.16905 \\
\hline Parental control & 3.5000 & .83666 \\
\hline Bandwidth manag. & 3.3333 & 1.50555 \\
\hline Data encryption & 3.3333 & 1.21106 \\
\hline Penetration testing & 3.1667 & 1.32916 \\
\hline Notification & 3.1667 & 1.32916 \\
\hline
\end{tabular}

Source: Research Data 
From the results in table 4.3 , it was found that to a great extent (mean $>4$ ) the ISPs have focused on employing antivirus applications, software and hardware firewalls, antispam applications, data recovery and staff training in an effort to control cybercrime in Nairobi. Although there is an indication that ISPs have tried to focus on ways of preventing cybercrime, other important areas such as parental control which can be an effective measure against cyberpornography and also penetration testing to identify loop holes that can be exploited by cybercriminals, haven't yet been optimized. From the statistics gathered on prevalent forms of cybercrime in Nairobi, it was observed that Cyberpornography which also encompassed childpornography was steadily on the increase, the use of parental control or enforcement of this feature could mean that this emerging crime can be controlled before it becomes a grave concern.

\section{Summary and Conclusions}

\section{Conclusions}

In line with the general objectives of the study, the following conclusions were arrived at.

Based on the results from data analysis and findings of the research, the study has revealed that cybercrime is silent but common even in developing countries like Kenya and the following conclusions were arrived at, based on the objective of the study; Firstly, it was observed that a number of cybercrime forms were prevalent in Nairobi most notably spamming, hacking, use of malicious code through viruses or trojans and lastly piracy. These ultimately pose a more security risk with the emergence of the submarine optic fibre which promise faster internet speeds through higher bandwidth and most importantly at cheaper and affordable rates, giving cyberspace criminals and added advantage at perpetuating there crimes. With the country and the government on the verge of instituting ecommerce to all its ministries in Kenya, it means that if strategies will not be put in place then there is a National Security risk posed through hacking, and cyberespionage where the government may stand to lose vital information or by having their websites denied access for instance, through denial of service bombs.

Secondly, the major focus on cybercrime employed by organizations in Nairobi was on providing means of curbing cybercrime that exist rather than finding ways of preventing them from occurring. As observed, currently spamming, hacking and piracy are at the forefront common forms of cybercrime employed by cyber criminals. ISPs especially,

are purchasing expensive antivirus applications and firewalls to remove virus infections while ignoring preventive solutions such as, blacklisting specific IPs that are related to crime, which could be either pornographical websites, phishing sites or even sites that are known to host viruses. In some first world countries, torrent sites that proliferate the piracy of copyrighted material are blacklisted as a government directive, through tough legislations.

Thirdly and most importantly is that organizations in Nairobi, that is, both ISPs, the CCK and the CID use a lot of resources in an effort to curb cybercrime. The Communications Commission of Kenya has set out on an exercise to educate consumers on cybercrime and other threats posed by the expected increase in Internet usage as a result of cheaper bandwidth. Expensive connectivity has limited the region's Internet penetration and electronic commerce is nonexistent, so, cybercriminals have not targeted that area as much as South Africa. The lack of awareness, ignorance and poor legislations have greatly contributed to slow progress against the fight against cybercrime.

Furthermore, it is hard to convict cyber criminals because of two major reasons. Firstly, few countries have enacted e-laws and the existing ones are not sufficient in convicting culprits because of jurisdiction anomalies especially when the investigation transcends international borders. Secondly, obtaining evidence of computer crime that would stand in courts of law is lacking in many countries since the field of computer forensics is still relatively new and lacks sufficient literature and expertise. Cyber crime is a 
serious threat to the security of cybercitizens and all countries should take it seriously.

From the above it is clear, beyond reasonable doubt that if proper strategies are no put in place to curb cyberspace crime especially with the recent internet development, then Cybercrime posses a great threat on Security in Nairobi.

\section{Recommendations, Limitations and Suggestion for Further Research}

Prevention is best solution to curb the increasing number of security violations on the net. However, it may not be feasible to prevent all incidents, and that is when two major factors come in play. Firstly, forensic knowledge and expertise, followed by the relevant laws that would empower victims to seek justice. This can be achieved through a number of measures discussed below.

There is a need for setting up a public facility (preferably with a presence on the internet) where victims can report incidences. The public need a lot of sensitization and training on what computer crimes are, in which forms they can manifest, how to detect them, what to do after detection and how to prevent and minimize them. The Police should also endeavor to build trust and confidence in the population by using the media and otherwise, so that more such incidents are reported to them for proper and unified record keeping.

Countries implementing Internet filtering at client, Internet Service Provider (ISP) and government levels would prevent access to illegal websites like those promoting concepts like drug use, gambling, immorality, and pornography, bomb making recipes, terrorism and the like. Legislative organs can mandate a body to filter all incoming web traffic before it is accessed by Internet users in that country and block away websites that pose security threats to the users. Internet Service Providers are also in position to protect their clients against most cyber attacks like distributed denial of service attacks, email spoofing, spam and the like if they were only allowed to do it.
Enacting global cyber laws that deal with harmonization and standardization of computer crime would bring us closer to attaining total justice to cybercrime victims. Although a number of countries have enacted cyber laws and have punished criminals within their jurisdiction, they are dominated by the developed countries. Most developing countries have not yet enacted e-laws. Harsh punishments should be given to defaulters so that people fear to commit these acts and victims be motivated to report them. This would prevent escalation of cases and further loss of money, time, data and equipment.

On the other hand, Third World countries like Kenya which already have laws related to cybercrime should have their legislations revised to keep up with the emerging cyberspace threats, as criminals are coming up with new tricks to evade the law and process of prosecution.

The greatest constraint in carrying out the research was time factor. Some of the respondents had little information hence giving out data which was not satisfactory and needed more input. Due to poor means of communication it took long to visit all branches and this led to arriving when some of the managers had left for meetings and others home, again because of shortage in time the research had to rely on telephone interviews. It also took a while when collecting the questionnaires because some of the respondents kept them or even failed to reply to the questionnaire sent via email. There was also poor coordination and assistance from government organizations that were critical to this study, especially the CCK (Communications Commission of Kenya) and also the Criminal Investigations Department (CID) who failed to present the research with vital statistics on cybercrime, the organizations insisted on a letter signed by the Commissioner of Police in order to access the materials which time could not allow.

Areas of further research that were identified include a similar study to be carried out on other sectors of the ICT sector, for instance cybercafés where cybercriminals identify to carry out their criminal activities. Other areas of study 
should include law enforcement and the fight against cybercrime that they employ in Nairobi Kenya, a vivid statistical data is vital in order to understand the dynamics of cybercrime and their threat to security. Crucially further research should be done to explore new techniques and procedures that will combat the rate at which cyber crime spreads and the ease at which they can be conducted.

\section{References}

Adomi, E.E. (2008). "Security and Software for Cybercafes," IGI, Global, USA.

Boon J. \& Sheridan L. (2002). "Stalking and Psychosexual Obsession: Psychological Perspectives for Prevention, Policing and Treatment," Wiley.

Chandler, A. (1996). "The Changing Definition and Image of Hackers in Popular Discourse," International Journal of the Sociology of Law.

Christopher C. Yang (2008). 'Intelligence and Security Informatics,' IEEE ISI 2008 international workshops,"

Coleman, J. W. (2002). The Criminal Elite: Understanding White-Collar Crime (6th ed.). Worth Publishers.

Council of Europe. Octopus Programme, (2004). Organised crime in Europe:the threat of cybercrime: situation report, Page 109.

Critcher, C. (2003). 'Moral Panics and the Media,' Buckingham: Open University Press.

Das, T. H. (1983). 'Qualitative Research in Organisational Behaviour,' Journal of management studies.

David Bell, (2004). "Cyberculture: The Key Concepts," Routledge.

David Wall, (2007). "Cybercrime, The Transformation of Crime in the Information Age," Polity

Debra Littlejohn Shinder, Ed Tittel. (2002). "Scene of The Cybercrime: Computer Forensics Handbook,"
D'Ovidio,R \& Doyle, J. (2003). "A Study on Cyberstalking: Understanding Investigative Hurdles," FBI law enforcement bulletin.

Giannis S., (2007). "Computer Ethics: A Global Perspective," Jones and Bartlett.

Giddens, A. (1990). 'The Consequences of Modernity,' Cambridge: Political Press.

Gordon S. \& Ford, R. (2004). 'Cyberterrorism? In: Cybterterrorism,' The International Library of Essays in Terrorism.

Grabosky P.N., Et al (2001). "Electronic Theft: Unlawful Acquisition in Cyberspace," Cambridge University Press.

Grimes, R. (2001). "Malicious Mobile Code, Virus Protection for Windows," O'Reilly.

H. Thomas Milhorn. (2007). 'Cybercrime: How to Avoid Becoming a Victim by - True Crime,'

Hossein Bidgoli. (2004). 'The Internet Encyclopedia,' Wiley.

Khosrowpour, M. (2004). "Innovations through Information Technology," Idea Group.

Kinyanjui, G. (2009). 'Editor, Business Daily,' Available: http://www.businessdailyafrica.com//539444/638794/-/rx1rgv/-/index.html

Kipper, G. (2007). 'Wireless Crime and Forensic Investigation,' Auerbach Publications.

Janczewski, L. \& Colarik, A. M. (2008). "Cyber Warfare and Cyber Terrorism," IGI Global.

Linden, E. V. (2007). "Focus on Terrorism," Nova Science, Inc.

Littlewood, A. (2003). "Cyberporn and Moral Panic: An Evaluation of Press Reactions to Pornography on the Internet," Library and Information Research, 27(86): 8-18. 
Mallory S, L. (2007). "Understanding Organized Crime," Jones and Bartlett.

Mann, D. \& Sutton, M. (1998). 'Netcrime: More Change in the Organisation of Thieving,' British Journal of Criminology.

McQuade, S. C. (2009). "Encyclopedia of Cybercrime," Greenwood Press, Westport USA.

Ngunjiri, M. (2008). 'Editor, The East African,' Available:

http://www.theeastafrican.co.ke/business /-/2560/486364/-/6ireoqz/-/index.html

Njoroge, C. K. (2008). "Director General,Communications Commission of Kenya", available: http://www.cck.go.ke/html/child.asp?cont catid=1\&childtitle=History $\% 20$ of $\% 20$ Inter net $\% 20$ in $\% 20$ Kenya\&child contid $=251$

Office of Investor Education and Assistance see:http://www.extension.org/pages/Inve sting_Unit_11:_Investment_Fraud 2009 Pratiyogita Darpan, June 2008 Magazine v. 2, no. 24.

Mollin, R. A. (2005). 'Codes: The Guide to Secrecy from Ancient to Modern Times,' Chapman \& Hall/CRC.

Richards, J. R. (1999). 'Transitional Criminal Organizations, Cybercrime, and money laundering,' CRC Press LLC, New York.

Roderic, G. Et al. (2004). 'Cyber-crime: The Challenge in Asia,'" University of Washington Press, USA.

Roderic, G. Et al. (2005). 'Cyber-crime: the challenge in Asia,' University of Washington Press, USA.

Schell, B. H. \& Clemens, M. (2004). "Cybercrime: A Reference Handbook," ABCCLIO.
Siegel, J. A., Saukko, P. J. \& Knupfer, G. C. (2000). 'Encyclopedia of Forensic Sciences,' Academic Press.

Stair, R. M. \& Reynolds. G. W. (2009). Principles of Information Systems (9th ed.). Cengage Learning. Sylvester, L. (2001). 'The Importance of Victimology in Criminal Profiling,'

Taylor, P. (1999). "Hackers: Crime in the Digital Sublime," Routledge, London

The Kenya Communications (Amendment) Act,

Available:http://www.cybercrimelaw.net/ Tushabe, F. \& Baryamureeba, V. (2005). "Cyber Crime in Uganda: Myth or Reality?,"

Wall, D. S. (2001). "Crime and the Internet," Routledge, London.

Wang, W., (2006). "Steal this Computer Book 4.0: What They Won't Tell You About the Internet," No starch Press.

Webster, F. (2003). Theories of the Information Society, 2nd edn. London: Routledge.

Yar, M. (2006). "Cybercrime and Society," SAGE Publications Ltd, India.

Yin, R. K. (1994). Case Study Research: Design and Methods, (2nd Edition). Newbury Park, Sage.

Zeviar-Geese (1998). "The State of the Law on Cyberjurisdiction and Cybercrime on the Internet," California Pacific School of Law, Gonzaga Journal of International Law, vol. 1.

Zeviar-Geese, G. (1997). "The State of the Law on Cyberjurisdiction and Cybercrime on the Internet," Gonzaga University. 


\section{Appendix I: Telecommunications Licensed Service Providers}

\begin{tabular}{|l|}
\hline INTERNET SERVICE PROVIDERS \\
\hline Ace Villa Development Co. Limited \\
\hline Africa One Ispeed Limited \\
\hline Africa Online Limited \\
\hline Alfa Solutions Limited \\
\hline Ameriken Telnet Kenya Limited \\
\hline Browse Internet Access Limited \\
\hline Callkey (EA) Limited \\
\hline Cam Communications Limited \\
\hline Communication Solutions Limited \\
\hline Copkenyan.Com Co Limited \\
\hline Data Net Options Limited \\
\hline Dialnet Communication Systems Limited \\
\hline Edgenet Limited \\
\hline EDP Limited \\
\hline Extreme Internet \\
\hline EZSAT Africa Limited \\
\hline Flexible Bandwidth Services Limited \\
\hline Geonet Communications Limited \\
\hline Global Broadband \\
\hline Limited Solution \\
\hline Inter Connect Limited \\
\hline IPHONE Global Limited \\
\hline ITNETS East Africa Limited \\
\hline Jambo Telkom Limited \\
\hline Karibu Networks Limited \\
\hline Karibu Telecom Limited \\
\hline Kenyaweb.Com \\
\hline Liam Telecommunications Limited \\
\hline Meteor Millennium \\
\hline Mitsuminet (K) Limited \\
\hline Mount Kenya Online Limited \\
\hline My ISP Limited \\
\hline Nairobinet (K) Limited \\
\hline Neotis Kenya Limited \\
\hline Niltel Kenya Limited \\
\hline Nirali Enterprises Limited \\
\hline Pace Setters Communication Network \\
\hline Philotronic Limited \\
\hline Pwani Telecomms Limited \\
\hline Rasmilink \\
\hline Sahannet Limited \\
\hline Sky Connection Limited \\
\hline Swyweb Technologies Limited Global (Kenya) Limited \\
\hline
\end{tabular}




\begin{tabular}{|l|}
\hline Liam Telecommunications Limited \\
\hline Meteor Millennium \\
\hline Mitsuminet (K) Limited \\
\hline Mount Kenya Online Limited \\
\hline My ISP Limited \\
\hline Nairobinet (K) Limited \\
\hline Neotis Kenya Limited \\
\hline Niltel Kenya Limited \\
\hline Nirali Enterprises Limited \\
\hline Pace Setters Communication Network \\
\hline Philotronic Limited \\
\hline Pwani Telecomms Limited \\
\hline Rasmilink \\
\hline Sahannet Limited \\
\hline Sky Connection Limited \\
\hline Skyweb Technologies Limited \\
\hline Swift Global (Kenya) Limited \\
\hline Swift Global (Kenya) Limited \\
\hline Texada Limited \\
\hline Todays Online Limited \\
\hline UUNET Kenya Limited \\
\hline Virtualsat Limited \\
\hline Wananchi Online Limited \\
\hline Web Engineering Limited \\
\hline Webrunner Limited \\
\hline
\end{tabular}

Appendix Ii: Questionnaire

\section{Part A: RESPONDENT PROFILE}

\section{Respondent Name (Optional)}

\begin{tabular}{|l|l|l|l|} 
1. (a) Gender (Please tick) & Male & Female
\end{tabular}

\section{(b) Department (Please tick your Department)}

\begin{tabular}{l|l|l|l|l}
\hline ICT & Others(name) & Name of the Section
\end{tabular}

(d) Grade (Please tick in the blank box next to your category )

\begin{tabular}{l|l} 
Senior Management & $\begin{array}{l}\text { Junior leve } \\
\text { management }\end{array}$
\end{tabular}

(e) Age Bracket (Please tick in the blank box next to your category )

\begin{tabular}{|l|l|l|l|l|l|l|}
\hline Below 25 & $25-35$ & & $36-45$ & $46-55$ & Over 55 \\
\hline
\end{tabular}

(e) What is your level of your Education? (Please tick)

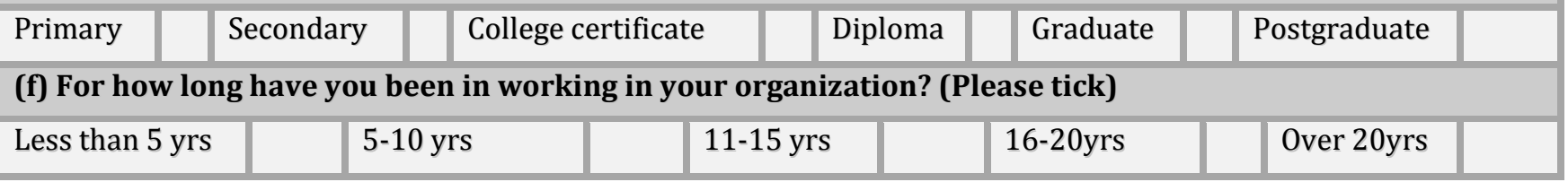




\section{Part B: CYBER- SECURITY IN YOUR ORGANIZATION}

a) Are you aware of the Cyberspace related crime? (1) Yes (2) No

b) How is your organization performing in the implementation of cyber-space security? (1) Very

Satisfactory (2) Satisfactory (3)

Dissatisfactory (4) Very Dissatisfied (5)

Don't Know

c) Can your organization implement the security strategies with available resources? Yes (2) No (3) not sure.... d) Are the cyber-space security strategies in your organization consistent with the cyber-space demands from internal and external environment? (1) Yes (2) No (3) not sure....

e) Are the cyber-space strategies in your organization consistent with the expectations of the CCK? (1) Yes (2) No (3) not sure....

\begin{tabular}{|c|l|l|l|l|l|}
\hline Form of cybercrime & $\begin{array}{l}\text { Very } \\
\text { Frequen } \\
\mathrm{t}\end{array}$ & $\begin{array}{l}\text { Frequen } \\
\mathrm{t}\end{array}$ & $\begin{array}{l}\text { Averag } \\
\mathrm{e}\end{array}$ & $\begin{array}{l}\text { Rar } \\
\mathrm{e}\end{array}$ & $\begin{array}{l}\text { Neve } \\
\mathrm{r}\end{array}$ \\
\hline i.) Spam mail/Junk mail & & & & & \\
\hline ii.) Denial of Service attacks (DOS) & & & & & \\
\hline iii.) Piracy $\quad$ Cyberstalking/Cyberharrassment & & & & & \\
\hline iv.) Cyberpornography/ & & & & & \\
\hline v.) Childpornography & & & & & \\
\hline vi.) Hacking & & & & & \\
\hline vii.) Cyberterrorism/Espionage & & & & & \\
\hline viii.) Phishing & & & & & \\
\hline ix.) Cyber-espionage & & & & & \\
\hline x.) Others (Specify ) & & & & & \\
\hline
\end{tabular}

Other form of cybercrime (Please add below) 
f) Are users given s prior notification from ICT about any new and emerging cyberspace threats? (1) Yes (2) No (3) Not sure.. g) What strategies have you employed to curb cybercrime? (Tick appropriate).

\begin{tabular}{|r|l|l|l|l|}
\hline i. & Measures & Yes & No & Dont Know \\
\hline ii. & Software Firewalls & & & \\
\hline iii. & Antispam Blockers & & & \\
\hline iv. & Data encryption & & & \\
\hline v. & Data recovery strategies. & & & \\
\hline vi. & Client/Customer behaviour policies on Cyberspace & & & \\
\hline vii. & Staff training awareness on Cyber threats & & \\
\hline viii. & Do you offer Parental Control Software & & & \\
\hline ix. & Penetration testing/ Ethical Hacking performed & & & \\
\hline x. & Bandwidth Management e.g. Sandvine & & & \\
\hline xi. & Hardware Firewall e.g. Cisco & & & \\
\hline
\end{tabular}

h) Your overall level of satisfaction

with the cyberspace security

system is (Tick one)

Very Satisfied

\section{Satisfied}

Dissatisfied

\section{Very Dissatisfied}




\section{Part C: CYBERSPACE SECURITY IMPLEMENTATION CHALLENGES}

\begin{tabular}{|c|c|c|c|c|c|c|}
\hline & $\begin{array}{l}\text { 1. To what extent do you agree with the } \\
\text { following attributes in Cyberspace } \\
\text { security implementation in your } \\
\text { organization (please tick as } \\
\text { appropriate) }\end{array}$ & $\begin{array}{l}\text { Very } \\
\text { Great } \\
\text { Extent }\end{array}$ & $\begin{array}{l}\text { Great } \\
\text { Extent }\end{array}$ & $\begin{array}{l}\text { Average } \\
\text { Extent }\end{array}$ & $\begin{array}{l}\text { Small } \\
\text { extent }\end{array}$ & $\begin{array}{l}\text { Very } \\
\text { Small } \\
\text { extent }\end{array}$ \\
\hline i.) & $\begin{array}{l}\text { Your organization has adequate and } \\
\text { sufficiently skilled personnel for } \\
\text { cyberspace security management. }\end{array}$ & & & & & \\
\hline ii.) & $\begin{array}{l}\text { Users are given adequate skills and } \\
\text { awareness to support cyberspace } \\
\text { security implementation. }\end{array}$ & & & & & \\
\hline iii.) & $\begin{array}{l}\text { Resistance to change is not experienced } \\
\text { in system's security implementation in } \\
\text { the organization. }\end{array}$ & & & & & \\
\hline iv.) & $\begin{array}{l}\text { During security implementations staff } \\
\text { sometimes ignore or refuse to stay on } \\
\text { track to fulfil their responsibilities. }\end{array}$ & & & & & \\
\hline v.) & $\begin{array}{l}\text { Your organization lacks adequate staff } \\
\text { in order for cyberspace security } \\
\text { implementation to be successful. }\end{array}$ & & & & & \\
\hline vi.) & $\begin{array}{l}\text { Refusal to use the security strategies is } \\
\text { experienced e.g. limited user account } \\
\text { rather than administrator. }\end{array}$ & & & & & \\
\hline vii.) & $\begin{array}{l}\text { Change management training is } \\
\text { conducted successfully during the } \\
\text { process. }\end{array}$ & & & & & \\
\hline viii.) & $\begin{array}{l}\text { Security softwares e.g antiviruses are } \\
\text { sufficiently evaluated during purchase, } \\
\text { hence product works as planned. }\end{array}$ & & & & & \\
\hline ix.) & $\begin{array}{l}\text { The implementation team always has } \\
\text { sufficient experience and are able to set } \\
\text { up the security systems properly. }\end{array}$ & & & & & \\
\hline x.) & $\begin{array}{l}\text { The security strategies are conducted } \\
\text { without affecting business process in } \\
\text { line with the budgeted cost and } \\
\text { timeline. }\end{array}$ & & & & & \\
\hline xi.) & $\begin{array}{l}\text { Compatibility issues during installation } \\
\text { e.g. hardware firewalls }\end{array}$ & & & & & \\
\hline xii.) & $\begin{array}{l}\text { Cost of the security implementation } \\
\text { strategies overruns the budget. }\end{array}$ & & & & & \\
\hline
\end{tabular}

Other Implementation issues (please explain)

.

.....................

i) What factors do you think hindered

the implementation process? j) Do you agree or disagree with the chosen method of security implementations and why? 
k) What future challenges do you expect to arise especially with the emergence of the fibre?

l) In your opinion are the current laws on cybercrime in Kenya sufficient? m) In your opinion, what can the government do to aid in the prevention of cyberspace crime? 